\title{
Risk Assessment of Heavy Metals in Imported Frozen Fish Scomber scombrus Species Sold in Nigeria: A Case Study in Zaria Metropolis
}

\author{
Abdullahi Abubakar, ${ }^{1}$ Adamu Uzairu, ${ }^{1}$ \\ Patricia Adamma Ekwumemgbo, ${ }^{1}$ and Oluwole Joshua Okunola ${ }^{2}$ \\ ${ }^{1}$ Department of Chemistry, Ahmadu Bello University, Zaria Kaduna State, Nigeria \\ ${ }^{2}$ Department of Applied Chemistry, Federal University Dutsin-Ma, PMB 5001 Dutsin-Ma, Katsina State, Nigeria
}

Correspondence should be addressed to Abdullahi Abubakar; aabubakar88@ymail.com

Received 7 September 2014; Revised 15 December 2014; Accepted 16 December 2014

Academic Editor: Ambuja Bale

Copyright (C) 2015 Abdullahi Abubakar et al. This is an open access article distributed under the Creative Commons Attribution License, which permits unrestricted use, distribution, and reproduction in any medium, provided the original work is properly cited.

\begin{abstract}
This study assesses the likely health risks to human contamination of heavy metals from fish consumption. The analysis of the idea of fish destination and status (fishing area) for heavy metals was determined by the assessment of its risk limits (daily intake of metal and health risk index). Variations in the accumulation of heavy metals concentrations were between various tissues/organs (skin, muscle, gills, liver, intestine, kidneys, brain, and bones) across the batches of two fishing origins. Post hoc (Duncan) multicomparison shows that there are significant differences $(P<0.05)$ across batches. The concentrations of heavy metals analyzed, in the investigated tissues of Scomber scombrus, showed higher levels of heavy metals accumulations in the order: $\mathrm{Fe}>\mathrm{Hg}>\mathrm{Pb}>\mathrm{Cd}>\mathrm{Ni}$ and were above the recommended safety limits outlined by FAO/WHO. However, the consumer's health risk with the consumption of fish muscles tissues shows that there are greater tendencies for cadmium, lead, and mercury exposure. Also consumption of Scomber scombrus species above the recommended daily intake (stated in this study) might lead to ingestion of heavy metals at unacceptable concentrations.
\end{abstract}

\section{Introduction}

Fish is a member of paraphyletic group of organisms consisting of gills bearing aquatic craniate animals that lack limbs and digits. They include the living hagfish, lampreys, and cartilaginous and bony fish, as well as various extinct related groups. Fish are abundant in most water bodies and as such this implied that they can be found in all aquatic environments, from high mountain streams to the abyssal deepest oceans. Fish exhibit greater diversity than any other class of vertebrates and consist of about 32800 species [1]. Fish are important resource for humans, especially as food, and commercial subsistence and have had a role in the culture through the ages, serving as deities, religious symbols, and the subjects of art, books, and movies. The use of fish by human was found since the advent of mankind and it was largely use as a source of food [2]. Fishing for food is an ancient practice that dates back to the beginning of the Paleolithic period, about 40,000 years ago [2]. Fishing has become an important part of human life such that the demand has led to involvement of both wild capture and aquaculture fisheries. However, the world is geared towards improvement of fish farming (aquaculture), although the wild capture fishing was still the leading sector that provides livelihoods and income for millions of people around the world [3].

Scomber scombrus fish species is a member of the large carangid family, which forms schooling species that resides close to the sea floor [4]. Heavy metal pollutants of water have become a major environmental concern, almost since the advent of agricultural and industrial revolution [5]. The threat of toxic metals in the environment was more serious, due to their nonbiodegradable nature and their long biological half-lives when accumulated [6]. They are difficult to read out completely from the environment once they entered [7]. 
Many of these metals tend to remain in the ecosystem and eventually move from one compartment to the other posing a treat within the food chain [8]. Fish are often representing the apex of food chain and hence are widely used to evaluate the health of ecosystem [9]. Fish bio-accumulate some metals in various tissues from their surrounding water and these can lead to death in the aquatic systems and humans $[10,11]$. In contrast, heavy metals tend to accumulate in the marine ecosystems by natural processes and tend to accumulate in fish tissues, subsequently transferred to higher trophic levels via food chain. Fish as the apex of food chain once affected the entire food chain would also be at high risk [9].

In Nigeria, there are limited reports on heavy metals safety assessment in imported frozen Scomber scombrus species. Several studies show that wild captured marine fish bio-accumulate heavy metals to a greater extent that can cause health consequences [12-17]. With the observed growth in fish consumption and low level of consumer safety control on imported frozen fish, across the country, this study investigated the risk of heavy metals in imported Scomber scombrus species against possible health hazards. Moreover, the objectives include determining the variation in the heavy metals accumulation in various fish tissues, the variation in the production batches, the impact of heavy metals pollutants on two major fishing zones (area), and the populations/individual health risk assessment with respect to recommendation of fish for daily intake.

\section{Experimental}

2.1. Quality Assurance. The reagents used in this work were of chemical grades from Sigma Company. Deionized water was used throughout the experimentation except otherwise was indicated. Dissecting surgical blades, plastic containers, and trays were washed with distilled water. Glass wares were soaked in $10 \% \mathrm{HNO}_{3}$ for 24 hours and rinsed with distilled water. All samples were digested along with the blanks in a clean laboratory environment. Quantification of metallic content of the digested samples and the blanks was carried out with the aid of Varian AA240 Fast Sequential Flame Atomic Absorption Spectrophotometer (AAS) and vapor generation accessory (Varian VGA 77) with closed end cell was used for $\mathrm{Hg}$ determination in Multi-User Science Research Laboratory (MSRL), Ahmadu Bello University, Zaria. In the absence of reference standard materials, the nitrate salts of the metals were used to prepare multielement standard solution (MESS) for spiking recoveries in the validation of digestion method. The analyzed samples were spiked and run in AAS again and the concentrations of the metal contents were determined from the calibration curve. The amounts of spiked metals recovered were used to calculate the percentage recoveries $(R \%)$ as follows:

$$
R \%=\frac{C 1-C 2}{C 3} \times 100
$$

where $C 1$ is the spiked sample result, $C 2$ is the un-spiked sample result, and $C 3$ is the concentration of the MESS.

Method validation by conducting limit of detection (LOD), limit of quantification (LOQ), and precision relative standard deviation $\left(\mathrm{RSD}_{r}\right)$ for repeatability within laboratory was also evaluated considering the six levels of standard solutions $(N=6)$ with concentration values ranging between 0.1 and $2.50 \mathrm{mg} \cdot \mathrm{kg}^{-1}$ which were prepared. Determination of metals concentrations was carried out in triplicate per sample of fish tissues. Dilution factors of the collected data were corrected by calculations and the values were presented in the units of $\mathrm{mg} \cdot \mathrm{kg}^{-1}$.

The authors determined LOD, LOQ, and RSD $\%$ based on the standard deviation of the blanks as follows:

$$
\begin{gathered}
\mathrm{LOD}=\bar{x}_{\text {blank }}+3 S_{\text {blank }}, \\
\mathrm{LOQ}=\bar{x}_{\text {blank }}+10 S_{\text {blank }}, \\
\mathrm{RSD}_{r} \%=\left(\frac{S}{\bar{x}}\right) \times 100,
\end{gathered}
$$

where $\bar{x}_{\text {blank }}$ is the mean of the blank aqueous solution and $S_{\text {blank }}$ is the blank standard deviation.

2.2. Fish Collection. Fish were collected from twelve (12) batches of Scomber scombrus species. Fish identity (noted on the carton leaflet) considered batches 1-6 were obtained from Russian fishing origins (RS) and batches 7-12 were from European fishing origins (EU). They were purchased from frozen fish market at Sabon-Gari, Zaria metropolis, Nigeria, and the samples were labeled, transported to the laboratory in clean polythene bags, and stored in refrigerator $\left(0^{\circ} \mathrm{C}\right)$ prior to experiment. Fish destination and some other general information were obtained from the cartons information leaflets. Since the cartons net weight was found to be less than $50 \mathrm{~kg}$, the incremental number of fish drown carton was based on the method recommended by FAO [18]. Thereby, three (3) incremental fish were drawn and composites from each batch of the carton, because some organs are tiny.

2.3. Fish Pretreatment and Dissection. Frozen fish samples were thawed, washed with distilled water, and then allowed to attain room temperature in desiccators before dissection. The skin and muscle were removed following Tru-cut method by Baker et al. [19]: scute skin was removed from the dorsal region on the first side of the fish sterilized notched needle. The outer barrel was inserted into the fish muscle tissue at an oblique angle (to minimize penetration depth). Notched needle was then extended into the flesh and the containment cover was slide over to cut the tissue and placed in a labeled plastic Petri dish. However, at the other side, the skin was cut off firmly making sure that no part of the muscle was attached and placed in its labeled drying dish.

Dissecting of gills, liver, intestine, kidney, brain, and bone tissues was based on the modified NIVA method by Rosseland et al. [20]. Dissections were done on plane plastic tray to separate sample organs. The operculum gill cover was lift up and cut to expose the entire gill arch, filament, and the rake and sampled out. The abdominal wall was cut through the tail where the bile bladder was removed from the liver and then pooled liver was also freed onto the abdominal wall and cut out. The whole intestine was cut out and placed into its drying container. The roof of the head was cut horizontally 
from the nostrils through the end of the skull in order to expose the brain and fetch out and cut accordingly. Vertebrae bones were defleshed and cut out entirely from the head to the tail. The organs were dried to constant weight at $80^{\circ} \mathrm{C}$ on plastic Petri dish and cooled in desiccators and powdered in porcelain mortar and pestle.

2.4. Digestion. The digestion of the sample organs were based on the microwave-assisted wet digestion method as described by Taghipour and Aziz [21]: $1 \mathrm{~g}$ dry weight samples organs were placed in polytetrafluoroethylene (PTFE) tube for microwave. Digestion reagents (mixtures of $6 \mathrm{~mL}$ ultrapure nitric acid, $65 \%$, and $2 \mathrm{~mL}$ hydrogen peroxide, 35\%) were added and placed in a microwave oven (with model number MW028A-MG720). The heating took place for 2 minutes and then cooled to temperature of $25^{\circ} \mathrm{C}$. The cleared solution was also diluted with deionized water to $50 \mathrm{~mL}$ for skin, muscle, gills, liver, intestine, kidney, brain, and liver. In contrast to the original method by Taghipour and Aziz [21], modification was made based on the adjustment of heating duration in microwave oven. In their work they used 20-minute period of digestion, but in this work, attempting to digest fish tissues samples beyond 2 minutes led the sample inside polytetrafluoroethylene (PTFE) tube to burn leaving behind carbon residue. Hence, our modification of this method came in digestion duration (2 min instead of $20 \mathrm{~min}$ ).

\section{Risk Assessment}

Risk assessment in this study was evaluated by considering only the edible part (muscles tissues) to determine daily intake of metal (DIM) and health risk index (HRI) according to methods by Khan et al. [22] and Okunola et al. [23].

3.1. Daily Intake of Metals (DIM). The daily intake of metals (DIM) was calculated to estimate the daily loading of metals into the body system (via the consumption of fish meal specified in this study) of a specified body weight of a consumer. This would entail the relative bioavailability of the studied metals in this study. The daily intake of metals (DIM) was determined by the following:

$$
\mathrm{DIM}=\frac{C_{\text {metal }} \times D_{\text {fish }} \times C_{\text {factor }}}{B_{\mathrm{o}}},
$$

where $C_{\text {metal }}$ is the concentration of heavy metals in the fish $\left(\mathrm{mg} \cdot \mathrm{kg}^{-1}\right), D_{\text {fish }}$ is the daily nutritional intake of fish (mg. day $^{-1}$ ), and $C_{\text {factor }}$ is the factor for conversion of fresh fish to dry constant weight. For Scomber scombrus species in this study, $C_{\text {factor }}$ was considered 0.3650 as computed by the equations below [24]. In this study, the daily intake of fish for nutritional requirement was $100 \mathrm{~g}$ for adults with average body weight of $70 \mathrm{~kg}$ (age range from 18 years and above), $80 \mathrm{~g}$ intake rate for children with average body weight of $48 \mathrm{~kg}$ (age range 6-18 years), and $60 \mathrm{~g}$ intake rate for children with average body weight of $19 \mathrm{~kg}$ (age range 6 years and below), recommending using the method by Portier et al. [25] as cited in USEPA [26] as follows:

$$
\begin{gathered}
C_{\text {factor }}=\mathrm{IR}_{\mathrm{ww}}-\mathrm{IR}_{\mathrm{dw}}, \\
\mathrm{IR}_{\mathrm{ww}}=\mathrm{IR}_{\mathrm{dw}}\left[\frac{100-W}{100}\right],
\end{gathered}
$$

where $I R_{d w}$ is the dry weight intake rate, $I R_{w w}$ is the wet weight intake rate, and $W$ is the percent of water content in the raw muscles (in this study was $63.50 \%$ ).

3.2. Health Risk Index (HRI). The health risk index (HRI) for the populations through the consumption of contaminated fish was assessed based on the daily intake of metals (DIM) relative to reference oral dose $\left(\mathrm{R}_{\mathrm{f}} \mathrm{D}\right)$ for each metal. This is an index justifying individual's risk of heavy metals. The HRI value of less than one (1) implies safe tread and is considered acceptable; otherwise, the fish may pose heavy metals risk. The following formula was used for the calculation of HRI:

$$
\mathrm{HRI}=\frac{\mathrm{DIM}}{\mathrm{R}_{\mathrm{f}} \mathrm{D}}
$$

3.3. Statistical Analysis. The data were expressed as the metal concentration in the tissues across the batches of the two fishing origins (RS and EU), with the means and standard deviation. To show whether there is significant difference between the batches, ANOVA was used followed by post hoc (Duncan) analysis. Pearson correlation $(r)$ was used to establish the degree of relationship among the tissues based on the analyzed metals across the fishing origins, using a statistical software package (IBM SPSS version 20).

\section{Results and Discussion}

4.1. Quality Assurance. As shown in Table 1, the results of validation parameters for the analytical procedures including recoveries of the spiked fish tissues obtained for the investigated metals ( $\mathrm{Cd}, \mathrm{Pb}, \mathrm{Hg}, \mathrm{Fe}$, and $\mathrm{Cd}$ ) were varied between the ranges of $93.60 \%$ to $118.70 \%$. Acceptable recoveries were obtained in all cases, which show that the digestion method used for fish samples tissues and the AAS analysis was reliable. Also, comparison of the recoveries data in this study showed that the values are within the range of $90-120 \%$ and these were in compliance with the Standard Operating Procedure (SOP) [26], Commission Decision [27], and European Commission Regulation [28]. The evaluated results for limit of detection (LOD), limit of quantification (LOQ), and the precision relative standard deviation $\left(\mathrm{RSD}_{r}\right)$ within laboratory repeatability validate the methods of experimental analysis used. The results in Table 1 with respect to the entire metals show the LOD values of specification of not more than one tenth and for LOQ values of not more than one fifth as specified by the USEPA regulation [26].

4.2. Metal Concentrations. The statistical analysis of heavy metals, cadmium, lead, mercury, iron, and nickel (Cd, $\mathrm{Pb}, \mathrm{Hg}$, $\mathrm{Fe}$, and $\mathrm{Ni}$ ), concentrations $\left(\mathrm{mg} \cdot \mathrm{kg}^{-1}\right)$ in the tissues/organs (skin, muscle, gills, liver, intestine, kidneys, brain, and bones) 
TABLE 1: Quality assurance for mean concentration of metals in tissues of batch one (1) Scomber scombrus species.

\begin{tabular}{|c|c|c|c|c|c|}
\hline Heavy metal & Tissues & $\begin{array}{c}\mathrm{LOD}\left(\mathrm{mg} \cdot \mathrm{kg}^{-1}\right) \\
\quad N=6\end{array}$ & $\begin{array}{c}\text { LOQ }\left(\mathrm{mg} \cdot \mathrm{kg}^{-1}\right) \\
N=6\end{array}$ & $\%$ Recovery \pm SD & $\% \mathrm{RSD}_{r}$ \\
\hline $\mathrm{Cd}$ & Skin & 0.058 & 0.109 & $103.8 \pm 0.25$ & 24.08 \\
\hline $\mathrm{Pb}$ & Muscle & 0.001 & 0.009 & $100.8 \pm 0.10$ & 9.92 \\
\hline $\mathrm{Hg}$ & Gills & 0.001 & 0.004 & $118.7 \pm 0.25$ & 23.56 \\
\hline $\mathrm{Fe}$ & Liver & $8.19 E-5$ & $2.67 E-4$ & $106.1 \pm 0.55$ & 51.84 \\
\hline $\mathrm{Ni}$ & Intestine & 0.012 & 0.042 & $99.2 \pm 0.15$ & 1.51 \\
\hline $\mathrm{Cd}$ & Kidneys & 0.009 & 0.029 & $93.6 \pm 0.30$ & 3.21 \\
\hline $\mathrm{Pb}$ & Brain & 0.003 & 0.009 & $103.4 \pm 0.35$ & 33.84 \\
\hline $\mathrm{Hg}$ & bones & 0.001 & 0.003 & $113.0 \pm 0.15$ & 13.27 \\
\hline
\end{tabular}

TABLE 2: Mean and standard deviation of metals concentrations in the tissues of Scomber scombrus $\left(\mathrm{mg}^{\mathrm{k}} \mathrm{kg}^{-1}\right.$ ) wet weight.

\begin{tabular}{|c|c|c|c|c|c|}
\hline Tissue & $\mathrm{Cd}(N=6)$ & $\mathrm{Pb}(N=6)$ & $\mathrm{Hg}(N=6)$ & $\mathrm{Fe}(N=6)$ & $\mathrm{Ni}(N=6)$ \\
\hline Skin (RS) & $2.133 \pm 0.025$ & $17.150 \pm 0.350$ & $72.425 \pm 0.030$ & $16.700 \pm 0.030$ & $6.158 \pm 0.010$ \\
\hline Skin (EU) & $1.158 \pm 0.035$ & $7.833 \pm 0.005$ & $66.542 \pm 0.040$ & $15.893 \pm 0.020$ & $9.025 \pm 0.010$ \\
\hline Muscle (RS) & $2.192 \pm 0.005$ & $15.133 \pm 0.010$ & $75.692 \pm 0.054$ & $11.453 \pm 0.020$ & $6.042 \pm 0.005$ \\
\hline Muscle (EU) & $2.375 \pm 0.015$ & $7.242 \pm 0.010$ & $73.400 \pm 0.015$ & $21.873 \pm 0.025$ & $8.942 \pm 0.050$ \\
\hline Gills (RS) & $2.425 \pm 0.015$ & $15.942 \pm 0.005$ & $75.925 \pm 0.005$ & $234.81 \pm 0.025$ & $6.650 \pm 0.010$ \\
\hline Gills (EU) & $1.125 \pm 0.020$ & $8.142 \pm 0.015$ & $80.358 \pm 0.005$ & $225.25 \pm 0.010$ & $9.067 \pm 0.015$ \\
\hline Liver (RS) & $19.758 \pm 0.030$ & $16.617 \pm 0.010$ & $70.900 \pm 0.010$ & $375.93 \pm 0.025$ & $6.650 \pm 0.020$ \\
\hline Liver (EU) & $10.658 \pm 0.015$ & $8.575 \pm 0.005$ & $73.958 \pm 0.020$ & $132.69 \pm 0.040$ & $8.108 \pm 0.015$ \\
\hline Intestine (RS) & $7.692 \pm 0.015$ & $17.533 \pm 0.020$ & $71.342 \pm 0.010$ & $233.88 \pm 0.045$ & $6.800 \pm 0.020$ \\
\hline Intestine (EU) & $5.492 \pm 0.035$ & $8.417 \pm 0.020$ & $75.875 \pm 0.025$ & $43.367 \pm 0.045$ & $8.558 \pm 0.010$ \\
\hline Kidneys (RS) & $4.267 \pm 0.040$ & $17.558 \pm 0.025$ & $72.125 \pm 0.015$ & $70.780 \pm 0.010$ & $7.017 \pm 0.005$ \\
\hline Kidneys (EU) & $5.408 \pm 0.030$ & $8.725 \pm 0.015$ & $66.600 \pm 0.030$ & $196.99 \pm 0.035$ & $8.650 \pm 0.005$ \\
\hline Brain (RS) & $2.958 \pm 0.015$ & $16.942 \pm 0.035$ & $76.000 \pm 0.010$ & $57.580 \pm 0.025$ & $6.517 \pm 0.100$ \\
\hline Brain (EU) & $1.600 \pm 0.010$ & $4.417 \pm 0.025$ & $68.650 \pm 0.020$ & $44.360 \pm 0.040$ & $8.233 \pm 0.015$ \\
\hline Bones (RS) & $6.208 \pm 0.010$ & $16.708 \pm 0.030$ & $72.850 \pm 0.030$ & $52.807 \pm 0.015$ & $6.767 \pm 0.010$ \\
\hline Bones (EU) & $1.608 \pm 0.020$ & $3.950 \pm 0.015$ & $70.558 \pm 0.020$ & $54.000 \pm 0.015$ & $8.167 \pm 0.010$ \\
\hline FAO/WHO [18] & 0.100 & 0.400 & 0.500 & - & - \\
\hline CCFAC [57] & - & - & - & 0.800 & - \\
\hline WHO [64] & - & - & - & - & 0.200 \\
\hline
\end{tabular}

$N$ is the number of batches analyzed.

of Scomber scombrus across two major fishing origins including the mean and standard deviation is summarized in Table 2. Analysis of variation between the fish samples collected from the two fishing zones, Russia (RS) and Europe (EU), and the sample batches within the same zone showed significant differences $(P<0.05)$.

4.2.1. Cadmium Concentrations. The results of cadmium mean concentrations in Table 2 show that the concentrations recorded in tissues of RS fish species ranged between $2.133 \mathrm{mg} \cdot \mathrm{kg}^{-1}$ and $19.758 \mathrm{mg} \cdot \mathrm{kg}^{-1}$ as shown for the skin and liver tissues, respectively. However, mean concentrations in the tissues of EU fish species ranged between $1.125 \mathrm{mg} \cdot \mathrm{kg}^{-1}$ and $10.658 \mathrm{mg} \cdot \mathrm{kg}^{-1}$ as shown for the gills and liver tissues, respectively. Statistical significant differences $(P<0.05)$ were established among the batches of both RS and EU tissues. In the batches of RS tissues, the significant differences $(P<0.05)$ were shown with the batches of skin and muscles tissues, whereas in the EU tissues, significant differences were shown with the batches of bones tissues only. The significant difference shown in the RS (skin and muscles) and EU (bones) tissues between batches implies that the cadmium contaminations were due to impacts from different sources. However, most of these tissues (with respect to both RS and EU fish species) showed nonsignificant differences across their batches and hence this gives an indication that the sources of cadmium are contaminated from similar sources.

The highest cadmium accumulations shown with both RS and EU species were found in batches of livers tissues, $19.758 \mathrm{mg} \cdot \mathrm{kg}^{-1}$ and $10.658 \mathrm{mg} \cdot \mathrm{kg}^{-1}$, respectively. This high level of cadmium shown in the liver tissues was in compliance with the reports found in many fish species. Storelli et al. [29] showed that $19.81 \mathrm{mg} \cdot \mathrm{kg}^{-1}$ was found in the liver tissues of Sphyrna zygaena species and Bashir et al. [12] showed that $13.35 \mathrm{mg} \cdot \mathrm{kg}^{-1}$ was in the liver tissues of $A$. thalassinus species samples collected from Mersing region. 
From the literature of fish studies, several reports were found in coinciding sequence that shows that high levela of cadmium are usually accumulated in the liver tissues [30-32]. In this study, the comparison of cadmium accumulations in the liver of Scomber scombrus from different fishing origins presented greater differences in concentration. Meanwhile, RS fish origins presented the highest level of cadmium in the liver, which indicates that RS fishing zone was rich in sources of cadmium contamination.

The higher levels of the cadmium shown in the liver relative to other tissues may be attributed to the high coordination of metallothionein protein with the cadmium [30]. In addition, the liver is the principal organ responsible for the detoxification, transportation, and storage of toxic substances [30]. It is an active site of pathological effects induced by contamination [30]. The relatively liver tissue that acts as the major storage organ of cadmium was reported in different species of fish studied in the Mediterranean Sea and northeast the Mediterranean Sea [33, 34]. However, the concentrations of cadmium shown in the intestine and kidneys tissues, irrespective of any batch, were higher than the results obtained for skin, gills, brain, and bones. This is because of their responsible roles in the process of absorption, storage, and excretion of ingested feed by the fish. This also entails that cadmium is stored in a state of binding form in the digestive tissues. Fish studies also show that absorption of cadmium from the gills or gastrointestinal tract mainly accumulates in the liver and kidneys $[35,36]$. Furthermore, the mean concentrations of cadmium shown with the entire tissues across the batches of both fishing zones were more pronounced and were above the safety limit specified by FAO [18]. This implies that both natural and anthropogenic activities such as seasonal changes, volcanic eruptions, different oceanic surge, and industrials discharge must have played a role in variations in the accumulation of cadmium across the batches with respect to both fishing zones.

4.2.2. Lead Concentrations. The results in Table 2 shows that the lead mean concentrations in tissues of RS fish origins ranged between $15.133 \mathrm{mg} \cdot \mathrm{kg}^{-1}$ and $17.558 \mathrm{mg} \cdot \mathrm{kg}^{-1}$ as shown for the muscles and kidneys tissues, respectively, while mean concentrations of lead in the tissues of EU fish species ranged between $3.950 \mathrm{mg} \cdot \mathrm{kg}^{-1}$ and $8.725 \mathrm{mg} \cdot \mathrm{kg}^{-1}$ as shown for bones and kidneys tissues, respectively. Statistical analysis showed that nonsignificant differences $(P<0.05)$ were established with the entire batches of both RS and EU tissues. The statistical results with respect to both RS and EU tissues show that nonsignificant differences are recorded with the entire batches and hence, these implied that the source of lead contaminations across the batches was highly homogeneous.

Accumulation of lead (with respect to both RS and EU fish species) was highly shown in the kidney tissues with concentrations of $17.558 \mathrm{mg} \cdot \mathrm{kg}^{-1}$ and $8.725 \mathrm{mg} \cdot \mathrm{kg}^{-1}$ as shown for RS and EU fish species, respectively. In comparison, RS fish species shows high level of lead accumulation in the kidneys than the corresponding EU fish species. Therefore, this indicates that RS fishing origin is highly contaminated with lead from different sources than corresponding EU fishing origin. The high levels of lead shown in the kidneys may be attributed to the high coordination of lead with the metallothionein protein present. Kidney is an organ next to the liver that plays a vital role in the process of digestion. Detoxifications of metals by the liver tissues mostly get accumulated in the kidneys [37]. Higher concentrations of lead are shown in the kidneys than in the liver tissues of RS fish which indicates that liver undergoes more detoxification process and in turns gets accumulated in the kidneys. This fact was in accordance with the study reported by Sahar et al. [38]. However, the muscles and bones tissues of both RS and EU fish were shown to accumulate least in lead concentrations. This result was in agreement with the studies by many authors, who reported that inactive tissues such as muscles and bones of fish cannot accumulate in heavy metals to such an extent that can reflect the metal concentration of the surrounding habitat [39-41]. The fact is that ingestion of lead and other metals takes place via eating by mouth and absorption through gills or skin. The entry through the ingestion path, flows to the intestine, then absorbed, processed and distributes by the liver and exit through kidneys. These parts are referred to as target active organs where bioaccumulation of lead can take place in the presence of mucus and metallothionein protein [42].

Lead is classified among the most toxic heavy metals which have no known biochemical benefits to animals and humans [43]. Lead continues to pose a serious threat to the health of many children as well as adults. Lead is capable of inducing oxidative damage to brain, heart, kidneys, and reproductive organs [44]. The mechanisms for lead-induced oxidative stress include the effects of lead on membranes, DNA, and antioxidant defense systems of cells [45]. Recent epidemiological and toxicological studies have reported that lead exposure causes several diseases including hypertension, kidney disease, neurodegenerative disease, and cognitive impairment. Scomber scombrus species generally shows some affinity for lead accumulation in all the analyzed tissues. The average mean concentrations of lead shown in all the tissues were found to exceed the safety limits recommended by FAO [18]. This was also found to be far above the concentrations reported by other studies in the Mediterranean Sea on fish tissues $[34,46,47]$.

4.2.3. Mercury Concentration. Table 2 shows that mercury mean concentrations for RS tissues ranged between $70.900 \mathrm{mg} \cdot \mathrm{kg}^{-1}$ and $76.000 \mathrm{mg} \cdot \mathrm{kg}^{-1}$ as shown for the liver and brain tissues, respectively, while for EU tissues, the concentrations of mercury ranged between $66.542 \mathrm{mg} \cdot \mathrm{kg}^{-1}$ and $80.358 \mathrm{mg} \cdot \mathrm{kg}^{-1}$ as shown for the skin and gills tissues, respectively. Except for the batches of bones tissues of RS origins, the statistical results of analysis show that nonsignificant differences $(P<0.05)$ were recorded across the rest of the batches, while EU fish origins show nonsignificant differences $(P<0.05)$ across the entire batches. This implies that mercury contamination was highly homogeneous as with fish from both origins.

The mean concentrations of mercury in the tissues of RS fish origins show high accumulation in the brain tissues $\left(76.000 \mathrm{mg} \cdot \mathrm{kg}^{-1}\right)$ and the least accumulation in the liver 
tissues $\left(70.900 \mathrm{mg} \cdot \mathrm{kg}^{-1}\right)$. For EU tissues, gills exhibit higher accumulations $\left(80.358 \mathrm{mg} \cdot \mathrm{kg}^{-1}\right)$ and the least was shown in the skin tissues $\left(66.542 \mathrm{mg} \cdot \mathrm{kg}^{-1}\right)$. Brain is a one of the vital organs in fish that stores high level of mercury [48]. Mieiro et al. [49] show that fish brain serves as the major critical target of mercury in the environmentally exposed fish. Mercury gets into the fish through ingestion or absorption via skin or gills from the surrounding water. Fish ingest contaminated mercuric food, flown through gastrointestinal tract, absorbed and gets distributed, accumulated or detoxified by the liver [50]. The revealed high concentrations of mercury shown in the gills of EU fish were due to direct exposure between the gills tissues and the surround water body. However, high level of mercury is shown with the entire tissues of fish from both RS and EU origins.

Excessive exposure to mercury is associated with a wide spectrum of adverse health effects including damage to the central nervous system (neurotoxicity) and the kidney of fish [3]. Hence, the accumulation levels of mercury shown in all the tissues was more pronounced and hence was above the concentrations reported by related studies on other fish species $[51,52]$. It was also found to exceed the recommended safety limit stated by FAO [18]. Furthermore, homogeneous contaminations of mercury shown with the entire tissues with respect to both RS and EU fish, suggested that the source contaminations was due to contaminations from both natural and anthropogenic activities. Natural occurrences were exhibited by spontaneous emission of the source contaminants as it does with volcanic eruption, oceanic surge, weathering/erosion, meteor deposition, and so forth, while daily lodgment of industrial, agricultural, and domestic human activities also contributes to the mercury bioavailability.

4.2.4. Iron Concentrations. Table 2 results show that mean concentrations for iron accumulation in RS tissues ranged between $11.443 \mathrm{mg} \cdot \mathrm{kg}^{-1}$ and $375.93 \mathrm{mg} \cdot \mathrm{kg}^{-1}$ as shown for the muscles and liver tissues, respectively, while mean concentrations recorded in EU tissues ranged between $15.893 \mathrm{mg} \cdot \mathrm{kg}^{-1}$ and $225.25 \mathrm{mg} \cdot \mathrm{kg}^{-1}$ as shown in the skin and gills tissues, respectively. The results of statistical analysis show that nonsignificant differences $(P<0.05)$ were shown across the entire batches for both RS and EU fish species. The frequent nonsignificant differences established in these batches of each of the fishing zones were due to homogeneity in the source of iron contaminations. This implied that there is spontaneous leaching of iron from the source contamination which may lead to the impact of high iron concentration across the entire batches.

With regard to both RS and EU fish species, Table 2 recorded that high iron concentrations were shown in the liver $\left(375.93 \mathrm{mg} \cdot \mathrm{kg}^{-1}\right)$ and gills $\left(225.25 \mathrm{mg} \cdot \mathrm{kg}^{-1}\right)$ tissues, respectively, while lower iron accumulations were shown in the muscles (11.443 mg. $\mathrm{kg}^{-1}$ ) and skin (15.893 $\mathrm{mg} \cdot \mathrm{kg}^{-1}$ ) tissues of RS and EU fish species. High levels of iron shown in the liver tissues were in accordance with the reports by Hjeltnes and Julshamn [53] who showed Atlantic salmon recorded as $246 \mathrm{mg} \cdot \mathrm{kg}^{-1}$ in the liver tissues, Erhan et al. [54] showed Liza abu recoded as $200.86 \mathrm{mg} \cdot \mathrm{kg}^{-1}$ in the liver tissues, and Bashir et al. [55] showed A. thalassinus and P. Anea recorded as $1007.1 \mathrm{mg} \cdot \mathrm{kg}^{-1}$ and $1975.0 \mathrm{mg} \cdot \mathrm{kg}^{-1}$ in the liver tissues, respectively. Liver as the principal organ for storage also stores iron to a certain higher level in Scomber scombrus. The higher level of the iron in the liver relative to other tissues may be attributed to the high coordination of iron with metallothionein protein [30]. Kumar and Mukherjee [56] and Mieiro et al. [13] found in coinciding sequences that liver tissues accumulate in iron more than as they do in any other tissues. The proclaimed of the results shows that, the high level of iron shown in the liver tissues may be related to the large volume of blood present in it which was not accounted for in this study. However, for EU tissues, gills were found to accumulate in high levels of iron and the results were nearly similar to the reports by Bashir et al. [55] who showed that $A$. thalassinus and $P$. anea recorded as $538.6 \mathrm{mg} \cdot \mathrm{kg}^{-1}$ and $299.5 \mathrm{mg} \cdot \mathrm{kg}^{-1}$ in their gills tissues, respectively. The high concentration of iron shown in the gills tissues can be related due to its direct contact with the water body and as a result, this would fairly entail the level of iron present in the surrounding water body where the fish lives. However, fish from both fishing origins show considerable levels of iron accumulated in the kidneys and intestine than the skin, brain, and bones. The lowest level of iron shown in the skin, brain, and bones was due to the fact that they are not active tissues. Generally, the level of iron shown with the entire tissues of both RS and EU fish origins were higher than the safety limits recommended by FAO/WHO [57]. Literature on iron interactions in biological tissues has reported that excess amount of iron causes rapid increase in pulse rate and coagulation of blood in blood vessels, hypertension, and drowsiness as cited in FAO [3]. Iron is an essential source for most forms of life. In humans, iron is an essential component of proteins involved in oxygen transported from the lungs to the tissues [3].

4.2.5. Nickel Concentrations. Nickel results in Table 2 show that mean concentrations in the tissues of RS fish species ranged between $6.042 \mathrm{mg} \cdot \mathrm{kg}^{-1}$ and $7.017 \mathrm{mg} \cdot \mathrm{kg}^{-1}$ as shown for the muscles and kidneys tissues, respectively, whereas the concentrations ranged between $8.108 \mathrm{mg} \cdot \mathrm{kg}^{-1}$ and $9.067 \mathrm{mg} \cdot \mathrm{kg}^{-1}$ as shown in the liver and gills tissues of EU fish species. The statistical analysis of variation shows that nonsignificant differences $(P<0.05)$ were recorded across the entire batches of both RS and EU fish origins. Since the tissues with respect to both RS and EU fish species show similarities of nickel uptakes across the entire tissues, contaminations were a result of similar sources. This implies that there is spontaneous leaching of nickel from the source contaminations which has impact across the entire batches of both origins.

Kidney tissues of RS fish species (Table 2) show high level of nickel accumulation with a concentration of $7.017 \mathrm{mg} \cdot \mathrm{kg}^{-1}$. Kidney is regarded as the major gateway for heavy metal detoxification in the body of fish apart from nitrogenous waste excretion, while the low levels of nickel shown in muscle tissues of RS fish species observed in this study coincide with the findings of trace metals bioaccumulation 
in several fish species by Israa et al. [58], Han et al. [59], and Erhan et al. [54]. In contrast, gills of EU tissues show high levels of nickel accumulations. Generally, the gills perform the function of respiration which is directly in contact with the metals present in the surrounding water and thus concentrations of heavy metals in gills reflect the concentration of metals in the water where the fish lives [30]. However, liver tissues with respect to EU fish species show low level of nickel accumulation and this gives an unusual report in the literature of nickel in fish. Hence, high nickel detoxification by the liver may in turns accumulations in the kidneys. Also level of nickel shown in the brain and bones was less pronounced, compared to the other tissues and this would be a result of low nickel mobility. However, the concentrations of nickel shown with the entire tissues with regard to both fishing zones were above the concentrations studied by many authors on marine fish ([60-63]) and also the concentrations were above the safety limits recommended by WHO [64].

The profile of studied heavy metals, $\mathrm{Cd}, \mathrm{Pb}, \mathrm{Hg}, \mathrm{Fe}$, and $\mathrm{Ni}$, in the analyzed tissues of Scomber scombrus species with respect to both fishing origins was summarized in the trends of accumulation pattern in this order: $\mathrm{Fe}>\mathrm{Hg}>$ $\mathrm{Pb}>\mathrm{Ni}>\mathrm{Cd}$. Iron concentrations across the entire tissues were extremely higher, compared to the concentrations of the other analyzed metals. The prevailed levels of iron can be related to contributions from both natural and anthropogenic activities that have impacts on the water body where these fish are brought. Natural activities such as meteor rays deposition are an example of frequent occurrence in the Mediterranean and Russian ocean that can contribute to level of iron concentrations. Iron is an essential trace element required by all forms of life. The effects of high doses of iron in animal studies are characterized by initial depression, coma, convulsion, respiratory failure, and cardiac arrest [65]. Postmortem examination reveals that excess iron intake is associated with adverse effects on the gastrointestinal track, which may lead to siderosis (deposition of iron in tissue), in liver, pancreas, adrenals, thyroid, pituitary, and heart [66]. These are characterized by initial depression, coma, convulsion, respiratory failure, and cardiac arrest [65]. Mercury is the second metal that was shown to accumulate highly in the tissues of Scomber scombrus. Mercury, as a nonessential element, is not expected to have its uptake/elimination actively regulated and subsequently its tissue concentrations can vary in a wide range, reflecting exposure to environmental levels and feeding behavior [67]. Hence, mercury body burdens in bioindicator species provide sensitive indications of aquatic pollution as well as the potential impact on human health [68]. However, the metal distribution within the body depends on both the fish species and the metal's properties [69]. The concentrations of lead and cadmium were also highly accumulated in the fish tissues. Nickel is the metal that showed the least accumulation among the others. Excess nickel exposures were associated with lung and nasal cancers [70]. Levels of heavy metals in the tissues of Scomber scombrus species were studied and found to be highly accumulated.

This implies that natural and anthropogenic human activities were essentially high in the destinations where this fish are brought. Occurrences nearby water bodies such as volcanoes, deposition of meteor rays, weathering, and erosion, as well as human activities, such as industrial, agricultural, domestic, mining, testing of hazardous substances from military facilities, vessels spills, chemical destruction in Mediterranean seas, oceanic surge, and so forth, may render high concentration of these heavy metals in the water body. Hence, in the later time these metals may accumulate in the aquatic life and in turn end up in human systems as hazardous substances. In general, the levels of the investigated metals were found to be highly above the safety limits recommended by FAO [18], irrespective of the batch and fishing area.

4.3. Risk Assessment. The risk assessment of heavy metals, $\mathrm{Cd}, \mathrm{Pb}, \mathrm{Hg}, \mathrm{Fe}$, and $\mathrm{Ni}$, concentrations $\left(\mathrm{mg} \cdot \mathrm{kg}^{-1}\right)$ in the muscle tissues of Scomber scombrus were carried out across the batches of both RS and EU fish origins; including ranges, average means, standard deviations, individuals variations (first category for adult of age 19 years, and above, second category for children of age 7-18 years and the last category for children of age 1-6 years), daily intake of metal (DIM) and health risk index (HRI) are summarized in Table 3.

The mean concentration of cadmium in the muscles tissues of Scomber scombrus species across twelve (12) batches (of both RS and EU fishing zones) was given as $2.284 \mathrm{mg} \cdot \mathrm{kg}^{-1}$. The assessments of individual's variation were based on the average body weight relative to ranges of age groups. The DIM results for individual's daily loading of cadmium were recorded with the values given as $1.162 \times 10^{-3}, 1.482 \times 10^{-3}$, and $2.633 \times 10^{-3} \mathrm{mg} \cdot \mathrm{kg}^{-1}$. These correspond to HRI ratio of greater than one (1) as shown for each of the individual's categories. The results also justify that individuals from any of the categories would be exposed to high dose of cadmium with the consumption of fish muscles based on equal or above the recommended daily intake values as specified in this study.

The mean concentration of lead in the muscles tissues of Scomber scombrus across twelve (12) batches was given as $11.188 \mathrm{mg} \cdot \mathrm{kg}^{-1}$. The results of DIM show individual's daily loading of lead given as $5.833 \times 10^{-3}, 7.559 \times 10^{-3}$, and $1.289 \times$ $10^{-2} \mathrm{mg} \cdot \mathrm{kg}^{-1}$. This corresponds to HRI with the ratio of values of greater than one (1), as shown with the entire categories. These results also indicate that the categories of the entire individuals would be exposed to the hazard of lead metals with the consumption of Scomber scombrus fish muscles based on the amount recommended for daily intake as specified in this study.

The mean concentration of mercury was found to be $74.546 \mathrm{mg} \cdot \mathrm{kg}^{-1}$ across the entire batches of both RS and EU fishing zones. The results of DIM recorded for individual's daily loading of mercury were given as $3.887 \times 10^{-2}, 4.837 \times$ $10^{-2}$, and $8.592 \times 10^{-2} \mathrm{mg} \cdot \mathrm{kg}^{-1}$. These correspond to HRI with the values of greater than one (1), as shown with each of the individual categories. Since the results shown for both HQ and HRI were above the ratio values of one (1). Hence, this indicates that the entire individuals consuming Scomber scombrus fish muscles of equal or above the recommended 
TABLE 3: Individuals DIM and HRI response for heavy metals in muscle tissues of Scomber scombrus species.

\begin{tabular}{|c|c|c|c|c|c|}
\hline Heavy metal & Range for 12 batches $\left(\mathrm{mg} \cdot \mathrm{kg}^{-1}\right)$ & Mean $\pm \mathrm{SD}\left(\mathrm{mg} \cdot \mathrm{kg}^{-1}\right)$ & Individuals & DIM (mg.kg ${ }^{-1}$ day $\left.^{-1}\right)$ & HRI \\
\hline \multirow{3}{*}{$\mathrm{Cd}$} & \multirow{3}{*}{$0.400-9.00$} & \multirow{3}{*}{$2.284 \pm 0.010$} & Adults (19 yrs and above) & $1.162 E-3$ & $1.056 E+0$ \\
\hline & & & Children (7-18 yrs) & $1.482 E-3$ & $1.482 E+0$ \\
\hline & & & Children (1-6 yrs) & $2.633 E-3$ & $2.632 E+0$ \\
\hline \multirow{3}{*}{$\mathrm{Pb}$} & \multirow{3}{*}{$2.00-21.750$} & \multirow{3}{*}{$11.188 \pm 0.010$} & Adults (19 yrs and above) & $5.833 E-3$ & $1.667 E+0$ \\
\hline & & & Children (7-18 yrs) & $7.559 E-3$ & $2.074 E+0$ \\
\hline & & & Children (1-6 yrs) & $1.289 E-2$ & $3.684 E+0$ \\
\hline \multirow{3}{*}{$\mathrm{Hg}$} & \multirow{3}{*}{$50.300-99.350$} & \multirow{3}{*}{$74.546 \pm 0.035$} & Adults (19 yrs and above) & $3.887 E-2$ & $3.887 E+2$ \\
\hline & & & Children (7-18 yrs) & $4.837 E-2$ & $4.837 E+2$ \\
\hline & & & Children (1-6 yrs) & $8.592 E-2$ & $8.592 E+2$ \\
\hline \multirow{3}{*}{$\mathrm{Fe}$} & \multirow{3}{*}{$6.040-59.160$} & \multirow{3}{*}{$16.663 \pm 0.023$} & Adults (19 yrs and above) & $8.689 E-3$ & $0.124 E-1$ \\
\hline & & & Children (7-18 yrs) & $1.081 E-2$ & $0.154 E-1$ \\
\hline & & & Children (1-6 yrs) & $1.921 E-2$ & $0.274 E-2$ \\
\hline \multirow{3}{*}{$\mathrm{Ni}$} & \multirow{3}{*}{$1.350-11.800$} & \multirow{3}{*}{$7.492 \pm 0.053$} & Adults (19 yrs and above) & $3.906 E-3$ & $0.195 E+0$ \\
\hline & & & Children (7-18 yrs) & $4.861 E-3$ & $0.243 E+0$ \\
\hline & & & Children (1-6 yrs) & $8.636 E-3$ & $0.432 E+0$ \\
\hline
\end{tabular}

yrs = years

amount for daily intake as specified in this study would be exposed to the hazard of mercury.

The mean concentration of iron in the muscles tissues of Scomber scombrus across the twelve (12) batches was given as $16.663 \mathrm{mg} \cdot \mathrm{kg}^{-1}$. The results of DIM recorded for individuals daily loading of iron were given as $8.689 \times 10^{-3}, 1.081 \times$ $10^{-2}$, and $1.921 \times 10^{-2} \mathrm{mg} \cdot \mathrm{kg}^{-1}$. These also correspond to HRI with values of less than one (1) as shown with each of the categories. However, the entire individual's population would not be exposed to high level of iron with the consumption of fish muscles based on the recommended daily intake as described in this study; otherwise, individuals would benefit from iron supplement.

The mean concentration of nickel in the muscles tissues of Scomber scombrus across twelve (12) batches was given as $7.492 \mathrm{mg} \cdot \mathrm{kg}^{-1}$. The results of DIM recorded for individuals daily loading of nickel were given as $3.906 \times 10^{-3}, 4.861 \times$ $10^{-3}$, and $8.636 \times 10^{-3} \mathrm{mg} \cdot \mathrm{kg}^{-1}$. These correspond to HRI in which each of the categories shows a value of less than one (1). Hence, this indicates that individuals belonging to any categories would not be exposed to high dose of nickel.

In summary, the results obtained based on the analysis of daily intake of metal (DIM) and health risk index (HRI) as presented in Table 3 show that the population of fish consumers in Zaria metropolis would be exposed to high loading dose of heavy metals: cadmium, lead, and mercury, at all levels with the consumption of Scomber scombrus species, while the levels of trace metals iron and nickel were still within acceptable limits.

\section{Conclusion}

The health status of humans with respect to contamination by heavy metals $(\mathrm{Cd}, \mathrm{Pb}, \mathrm{Hg}, \mathrm{Fe}$, and $\mathrm{Ni}$ ) in the imported frozen Scomber scombrus fish sold in Zaria metropolis was evaluated in this study. Based on the analysis obtained, there is significant risk of human exposure of heavy metals regarding consumption of Scomber scombrus species obtained from RS and EU fishing origins. Also, the risks from consumption of any fish tissues were very high, since the levels of heavy metals analyzed in the entire tissues were above their corresponding permissible limits recommended by FAO/WHO [18], CCFAC [57], and WHO [64]. However, individuals consuming fish livers may face considerable risk from ingestion of toxic metals at unacceptable concentrations. Since such hazards would be the case, it is recommended to improve aquaculturefishing practice across the country that will eliminate the risk of contaminations. Basically aquaculture practice can give rise to hazard control upon fish habitat, assessing and making the food free from contaminations. Finally, this work may provide valuable database for continuing research on the import of frozen fish in Nigeria.

\section{Conflict of Interests}

The authors declare that there is no conflict of interests regarding the publication of this paper.

\section{Acknowledgments}

The authors wish to acknowledge the entire staff of Chemistry Department, the staff of Multi-User Science Research Laboratory, and in person Aliyu Ibrahim Mu'azzamu Department of Pharmacology, Ahmadu Bello University, Zaria, for their support and analytical assistance.

\section{References}

[1] Fish Base, Fish species, common names, pictures, references and collaborators, ver. 2014, http://www.fishbase.org/search.php.

[2] Y. Hu, H. Shang, H. Tong et al., "Stable isotope dietary analysis of the Tianyuan 1 early modern human," Proceedings of the National Academy of Sciences of the United States of America, vol. 106, no. 27, pp. 10971-10974, 2009. 
[3] FAO, The state of world review of fisheries and aquaculture. Part 1, 2012, http://www.fao.org/docrep/016/i2727e/i2727e01.pdf.

[4] International Council for the Exploration of the Sea (ICES), "Working group on the assessment of mackerel, horse mackerel, sardine and anchovy," Tech. Rep. 2001/ACFM:6, ICES C. M., 2001.

[5] S. Hayat and M. Javed, "Regression studies of planktonic productivity and fish yields with reference to physico-chemical parameters of the ponds stocked with sub-lethal metal stressed fish," International Journal of Agriculture and Biology, vol. 10, no. 2, pp. 561-565, 2008.

[6] E. A. Oluyemi and I. O. Olabanji, "Heavy metals determination in some species of frozen fish Soldat Ile-Ife main market," Ife Journal of Science, vol. 13, no. 2, pp. 86-93, 2011.

[7] O. J. Aderinola, E. O. Clarke, O. M. Olarinmoye, V. Kusemiju, and M. A. Anatekhai, "Heavy metals in surface water, sediments, fish and periwinkles of Lagos lagoon," AmericanEurasian Journal of Agricultural \& Environmental Sciences, vol. 5, no. 5, pp. 609-617, 2009.

[8] R. S. Lokhande, P. U. Singare, and D. S. Pimple, "Quantification study of toxic heavy metal pollutants in sediment samples collected from Kasardi river flowing along the Taloja industrial area of Mumbai, India," New York Science Journal, vol. 4, no. 9, pp. 6-14, 2011.

[9] A. W. Trites, V. Christensen, and D. Pauly, "Effects of fisheries on ecosystems: just another top predator?" in Top Predators in Marine Ecosystems: Their Role in Monitoring and Management, I. L. Boyd, S. Wanless, and C. J. Camphuysen, Eds., pp. 11-27, Cambridge University Press, Cambridge, Mass, USA, 2006.

[10] S. A. Mansour and M. M. Sidky, "Ecotoxicological studies. 3. Heavy metals contaminating water and fish from Fayoum Governorate, Egypt," Food Chemistry, vol. 78, no. 1, pp. 15-22, 2002.

[11] A. Farkas, J. Salánki, and A. Specziár, "Relation between growth and the heavy metal concentration in organs of bream Abramis brama L. populating Lake Balaton," Archives of Environmental Contamination and Toxicology, vol. 43, no. 2, pp. 236-243, 2002.

[12] F. H. Bashir, M. S. Othman, A. G. Mazlan, S. M. Rahim, and K. D. Simon, "Heavy metal concentration in fishes from the coastal waters of Kapar and Mersing, Malaysia," Turkish Journal of Fisheries and Aquatic Sciences, vol. 13, no. 2, pp. 375-382, 2013.

[13] C. L. Mieiro, J. P. Coelho, M. Pacheco, A. C. Duarte, and M. E. Pereira, "Trace elements in two marine fish species during estuarine residency: non-essential versus essential," Marine Pollution Bulletin, vol. 64, no. 12, pp. 2844-2848, 2012.

[14] P. Hajeb, S. Jinap, A. Ismail, A. B. Fatimah, B. Jamilah, and M. Abdul Rahim, "Assessment of mercury level in commonly consumed marine fishes in Malaysia," Food Control, vol. 20, no. 1, pp. 79-84, 2009.

[15] A. B. Yilmaz, "Levels of heavy metals (Fe, Cu, Ni, Cr, Pb, and Zn) in tissue of Mugil cephalus and Trachurus mediterraneus from Iskenderun Bay, Turkey," Environmental Research, vol. 92, no. 3, pp. 277-281, 2003.

[16] F. E. Olaifa, A. K. Olaifa, A. A. Adelaja, and A. G. Owolabi, "Heavy metal contamination of Clariasgarpinus from a lake and Fish farm in Ibadan, Nigeria," African Journal of Biomedical Research, vol. 7, no. 3, pp. 145-148, 2010.

[17] F. M. J. Brown and P. W. Balls, "Trace metals in fish and shellfish from Scottish waters," Scottish Fisheries Research Report No. 60, Environment and Fisheries Department, The Scottish Office Agriculture, 1997.
[18] FAO, Heavy Metals Regulations: Part 1. Legal Notice no. 66, 2003, http://www.faolex.fao.org/docs/pdf/eri42405.pdf.

[19] R. F. Baker, P. J. Blanchfield, M. J. Paterson, R. J. Flett, and L. Wesson, "Evaluation of nonlethal methods for the analysis of mercury in fish tissue," Transactions of the American Fisheries Society, vol. 133, no. 3, pp. 568-576, 2004.

[20] B. O. Rosseland, J. C. Massabuau, J. Grimalt et al., Fish Ecotoxicology: The EMERGE Fish Sampling Manual for Live Fish, The EMERGE Project (European Mountain Lake Ecosystems: Regionalisation, Diagnostic and Socio-Economic Valuation), 2001, http://www.mountain-lakes.org/emerge/methods/29.pdf.

[21] V. Taghipour and S. N. Aziz, "Determination of trace elements in canned Kilka fish marketed in Islamic Republic of Iran," World Applied Sciences Journal, vol. 9, no. 6, pp. 704-707, 2010.

[22] S. Khan, R. Farooq, S. Shahbaz, M. A. Khan, and M. Sadique, "Health risk assessment of heavy metals for population via consumption of vegetables," World Applied Sciences Journal, vol. 6, no. 12, pp. 1602-1606, 2009.

[23] O. J. Okunola, Y. Alhassan, G. G. Yebpella et al., "Risk assessment of using coated mobile recharge cards in Nigeria," Journal of Environmental Chemistry and Ecotoxicology, vol. 3, no. 4, pp. 80-85, 2011.

[24] USEPA, "Intake of fish and shellfish," in Child-Specific Exposure Factors Handbook, Chapter 10, Office of Research and Development, Washington, DC, USA, 2008.

[25] K. Portier, J. Keith Tolson, and S. M. Roberts, "Body weight distributions for risk assessment," Risk Analysis, vol. 27, no. 1, pp. 11-26, 2007.

[26] USEPA, Exposure Factors Handbook: 2011 Edition, EPA/600/R090/052F, Office of Research and Development, Washington, DC, USA, 2011.

[27] Commission Decision 2002/657/EC, Implementing Council Directive 96/23/EC concerning the performance of analytical methods and the interpretation of results, European Union, 2002, http://faolex.fao.org/cgi, http://dx.bin/faolex.exe?rec_id $=040116$.

[28] European Commission Regulation, "Laying down the sampling methods and the methods of analysis for the official control of the lead, cadmium, mercury, inorganic tin, 3-MCPD and benzo (a) pyrene in foodstuffs," Tech. Rep. 333/2007, 2007.

[29] M. M. Storelli, G. Normanno, G. Barone et al., "Toxic metals $(\mathrm{Hg}, \mathrm{Cd}$, and $\mathrm{Pb})$ in fishery products imported into italy: suitability for human consumption," Journal of Food Protection, vol. 75, no. 1, pp. 189-194, 2012.

[30] A. Uzairu, G. F. S. Harrison, M. L. Balarabe, and J. C. Nnaji, "Concentration levels of trace metals in fish and sediment from Kubanni River, Northern Nigeria," Bulletin of the Chemical Society of Ethiopia, vol. 23, no. 1, pp. 9-17, 2009.

[31] F. Yilmaz, "The comparison of heavy metal concentrations (Cd, $\mathrm{Cu}, \mathrm{Mn}, \mathrm{Pb}$, and $\mathrm{Zn}$ ) in tissues of three economically important fish (Anguilla anguilla, Mugil cephalus and Oreochromis niloticus) inhabiting Koycegiz Lake-Mugla (Turkey)," Turkish Journal of Science Technology, vol. 4, pp. 11-15, 2009.

[32] A. S. Abolfazl and M. Maryam, "Comparison of mercury and cadmium toxicity in fish species from marine water," Research Journal of Fisheries and Hydrobiology, vol. 7, no. 1, pp. 14-18, 2012.

[33] C. Copat, G. Arena, M. Fiore et al., "Heavy metals concentrations in fish and shellfish from eastern Mediterranean Sea: consumption advisories," Food and Chemical Toxicology, vol. 53, pp. 33-37, 2013. 
[34] M. O. Yazkan, F. Zedemir, and M. Golukcu, "Cu, Zn, Pb and Cd content in some fish species caught in the Gulf of Antalya," Turkish Journal of Veterinary and Animal Sciences, vol. 26, no. 6, pp. 1309-1313, 2002.

[35] H. Fazli, C. I. Zhang, D. E. Hay, and C.-W. Lee, "Stock assessment and management implications of anchovy kilka (Clupeonella engrauliformis) in Iranian waters of the Caspian Sea," Fisheries Research, vol. 100, no. 2, pp. 103-108, 2009.

[36] M. Kalay and M. Canli, "Elimination of essential (Cu and Zn) and non-essential $(\mathrm{Cd}$ and $\mathrm{Pb})$ metals from tissues of a fresh water fish, Tilapia zillii," Tropical Journal of Zoology, vol. 24, no. 1, pp. 429-436, 2000.

[37] A. M. Yousafzai, A. R. Khan, and A. R. Shakoori, “Trace metal accumulation in the liver of an endangered south Asian fresh water fish dwelling in sub-lethal pollution," Pakistan Journal of Zoology, vol. 41, no. 1, pp. 35-41, 2009.

[38] M. Sahar, P. Alireza, and R. Afshari, "Analysis and determination of trace metals (nickel, cadmium, chromium, and lead) in tissues of Pampus argenteus and Platycephalus indicus in the Hara Reserve, Iran," Journal of Toxicology, vol. 2014, Article ID 576496, 6 pages, 2014.

[39] F. Asante, E. Agbeko, G. Addae, and A. K. Quainoo, "Bioaccumulation of heavy metals in water, sediments and tissues of some selected fishes from the Red Volta, Nangodi in the upper east region of Ghana," British Journal of Applied Science \& Technology, vol. 4, no. 4, pp. 594-603, 2014.

[40] E. S. Ishaq, S. Rufus, and P. A. Annune, "Bioaccumulation of heavy metals in fish (Tilapia zillii and Clarias Gariepinus) organs from River Benue, North-Central Nigeria," Pakistan Journal of Analytical \& Environmental Chemistry, vol. 12, no. 1, pp. 25-31, 2011.

[41] H. Karadede, S. A. Oymak, and E. Ünlü, "Heavy metals in mullet, Liza abu, and catfish, Silurus triostegus, from the Atatürk Dam Lake (Euphrates), Turkey," Environment International, vol. 30, no. 2, pp. 183-188, 2004.

[42] A. K. NoikHasyimah, V. James Noik, Y. Y. Teh, C. Y. Lee, and H. C. PearlineNg, "Assessment of cadmium $(\mathrm{Cd})$ and lead $(\mathrm{Pb})$ levels in commercial marine fish organs between wet markets and supermarkets in Klang Valley, Malaysia," International Food Research Journal, vol. 18, pp. 795-802, 2011.

[43] R. Singh, N. Gautam, A. Mishra, and R. Gupta, "Heavy metals and living systems: an overview," Indian Journal of Pharmacology, vol. 43, no. 3, pp. 246-253, 2011.

[44] A. El-Ghasham, E. E. Mehanna, and M. Abdel-Reheem, "Evaluation of lead and cadmium levels in fresh water fish farms at Qassim region," Journal of Agricultural and Veterinary Sciences, vol. 1, no. 2, pp. 59-77, 2008.

[45] D. N. Weber and W. M. Dingel, "Alterations in neurobehavioral responses in fishes exposed to lead and lead-chelating agents," American Zoologist, vol. 37, no. 4, pp. 354-362, 1997.

[46] M. A. Ogundiran, S. O. Adewoye, T. A. Ayandiran, and S. O. Dahunsi, "Heavy metal, proximate and microbial profile of some selected commercial marine fish collected from two markets in south western Nigeria," African Journal of Biotechnology, vol. 13, no. 10, pp. 1147-1153, 2014.

[47] A. Soegianto, B. Irawan, and I. Hamami, "Bioaccumulation of heavy metals in aquatic animals collected from coastal waters of Gresik, Indonesia," Asian Journal of Water, Environment and Pollution, vol. 1, no. 6, pp. 95-100, 2009.

[48] C. L. Mieiro, M. Pacheco, M. E. Pereira, and A. C. Duarte, "Mercury distribution in key tissues of fish (Liza aurata) inhabiting a contaminated estuary-implications for human and ecosystem health risk assessment," Journal of Environmental Monitoring, vol. 11, no. 5, pp. 1004-1012, 2009.

[49] C. L. Mieiro, M. E. Pereira, A. C. Duarte, and M. Pacheco, "Brain as a critical target of mercury in environmentally exposed fish (Dicentrarchus labrax)-bioaccumulation and oxidative stress profiles," Aquatic Toxicology, vol. 103, no. 3-4, pp. 233-240, 2011.

[50] H. F. A. Al-Balawi, A. S. Al-Akel, F. Al-Misned et al., "Effects of sub-lethal exposure of lead acetate on histopathology of gills, liver, kidney and muscle and its accumulation in these organs of Clarias gariepinus," Brazilian Archives of Biology and Technology, vol. 56, no. 2, pp. 45-56, 2013.

[51] J. S. Menon and S. V. Mahajan, "Mercury accumulation in different tissues of fish from Ulhas River Estuary and Thane Creek and the pattern of fish consumption among fish-eaters," Indian Journal of Marine Sciences, vol. 42, no. 6, pp. 812-816, 2013.

[52] L. Herger and L. Edmond, "Assessment of mercury in fish tissue from select lakes of Northeastern Oregon," Tech. Rep. EPA910-R-12-001, U.S. Environmental Protection Agency Region 10, 2012.

[53] B. Hjeltnes and K. Julshamn, "Concentrations of iron, copper, zinc and selenium in liver of Atlantic salmon Salmo salar infected with Vibrio salmonicida," Diseases of Aquatic Organisms, vol. 12, pp. 147-149, 1992.

[54] U. Erhan, K. Hulya, and A. O. Seyit, "Heavy metals in mullet, Liza abu, and catfish, Silurus triostegus, from the Atatürk Dam Lake (Euphrates), Turkey," Environment International, vol. 30, no. 2, pp. 183-188, 2004.

[55] F. A. Bashir, M. Shuhaimi-Othman, and A. G. Mazlan, "Evaluation of trace metal levels in tissues of two commercial fish species in Kapar and Mersing coastal waters, Peninsular Malaysia," Journal of Environmental and Public Health, vol. 2012, Article ID 352309, 10 pages, 2012.

[56] B. Kumar and D. P. Mukherjee, "Assessment of human health risk for arsenic, copper, nickel, mercury and zinc in fish collected from tropical wetlands in India," Advances in Life Science and Technology, vol. 2, pp. 13-25, 2011.

[57] CCFAC (Codex Committee on Contaminants in Foods), Food Standards Programed: Joint FAO/WHO, Fifth Session, CCFAC (Codex Committee on Contaminants in Foods), The Hague, The Netherlands, 2011.

[58] A. J. Israa, H. Z. Luma, and M. A. Rana, "Bacterial and heavy metals analyses in fish at Shawaka area of Tigris River," Chemistry and Materials Research, vol. 3, no. 7, pp. 94-100, 2013.

[59] B.-C. Han, W. L. Jeng, R. Y. Chen, G. T. Fang, T. C. Hung, and R. J. Tseng, "Estimation of target hazard quotients and potential health risks for metals by consumption of seafood in Taiwan," Archives of Environmental Contamination and Toxicology, vol. 35, no. 4, pp. 711-720, 1998.

[60] K. Ahsan, M. Siraj, M. Shaheen et al., "A comparative study of bioaccumulation of heavy metals in twofresh water species, Aorichthys seenghala and Ompok bimaculatous at River Kabul, Khyber Pakhtunkhwa, Pakistan," Journal of Biodiversity and Environmental Sciences, vol. 4, no. 3, pp. 40-54, 2014.

[61] U. Damodhar and M. Vikram, "Assessment of heavy metals concentrations in water and four fish species from the Uppanar River at Cuddalore (Tamil Nadu, India)," Continental Journal of Environmental Sciences, vol. 6, no. 3, pp. 32-41, 2012.

[62] A. Khaled, "Heavy metal concentrations in certain tissues of five commercially important fishes from El-Mex Bay, Alexandria," 
Egyptian Journal of Aquatic Biology and Fisheries, vol. 8, no. 4, pp. 51-64, 2004.

[63] J. Kojadinovic, M. Potier, M. Le Corre, R. P. Cosson, and P. Bustamante, "Bioaccumulation of trace elements in pelagic fish from the Western Indian Ocean," Environmental Pollution, vol. 146, no. 2, pp. 548-566, 2007.

[64] WHO, "Background document for development of WHO guidelines for nickel in drinking-water quality and fish," Tech. Rep. WHO/Sde/Wsh/05.08/55, 2005.

[65] P. A. Annune and T. T. Iyaniwura, "Accumulation of two trace metals in tissues of freshwater fishes, Oreochoromis niloticus and Clarias gariepinus," Journal of Aquatic Food Product Technology, vol. 2, no. 3, pp. 5-18, 1994.

[66] A. K. A. Taweel, M. Shuhaimi-Othman, and A. K. Ahmad, "Heavy metals concentration in Tilapia fish (Oreochromis niloticus) from four selected markets in Selangor, Peninsular Malaysia," Journal of Biological Sciences, vol. 10, no. 55, pp. 15621566, 2012.

[67] R. Capelli, K. Das, R. D. Pellegrini et al., "Distribution of trace elements in organs of six species of cetaceans from the Ligurian Sea (Mediterranean), and the relationship with stable carbon and nitrogen ratios," Science of the Total Environment, vol. 390, no. 2-3, pp. 569-578, 2008.

[68] P. Kotze, H. H. du Preez, and J. H. J. van Vuren, "Bioaccumulation of copper and zinc in Oreochromis mossambicus and Clarias gariepinus, from the Olifants River, Mpumalanga, South Africa," Water SA, vol. 25, no. 1, pp. 99-110, 1999.

[69] Z. Kljaković Gašpić, T. Zvonarić, N. Vrgoč, N. Odžak, and A. Barić, "Cadmium and lead in selected tissues of two commercially important fish species from the Adriatic Sea," Water Research, vol. 36, no. 20, pp. 5023-5028, 2002.

[70] T. K. Grimsrud, S. R. Berge, T. Haldorsen, and A. Andersen, "Exposure to different forms of nickel and risk of lung cancer," The American Journal of Epidemiology, vol. 156, no. 12, pp. 11231132, 2002. 

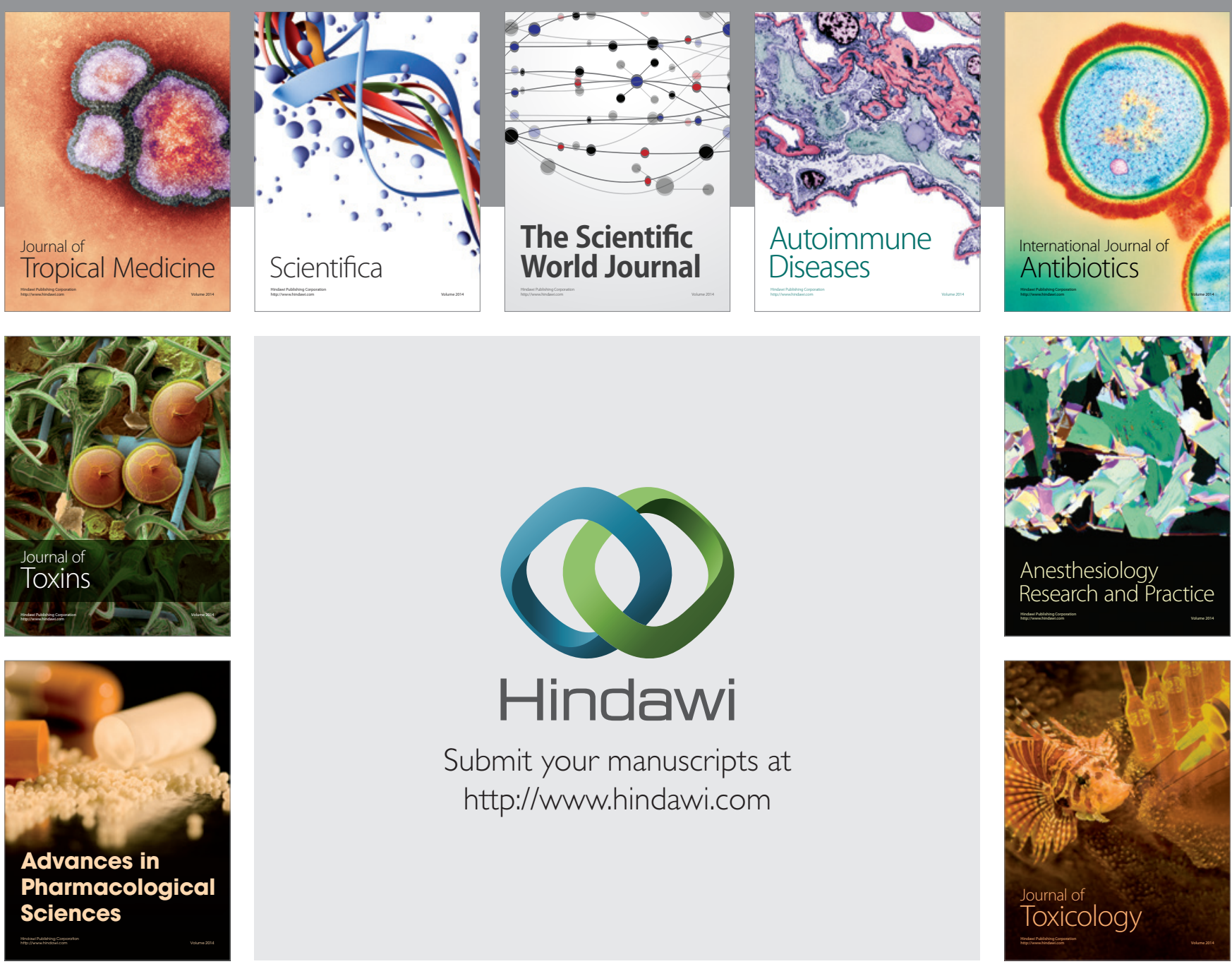

\section{Hindawi}

Submit your manuscripts at

http://www.hindawi.com
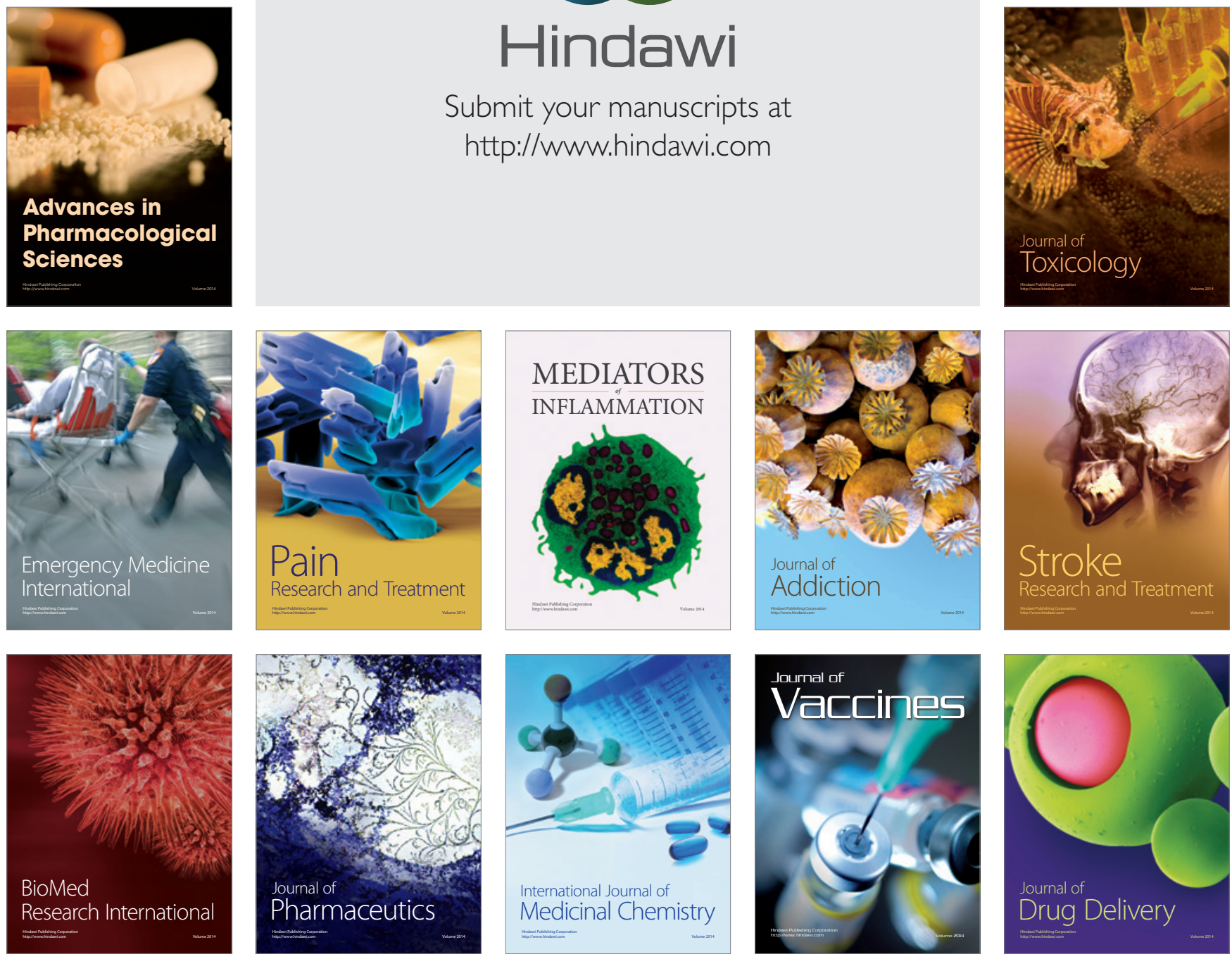